\title{
Physiological mechanism of osmoregulatory adaptation in anguillid eels
}

\author{
Quanquan Cao • Jie Gu • Dan Wang • Fenfei Liang • \\ Hongye Zhang $\cdot$ Xinru Li $\cdot$ Shaowu Yin
}

Received: 10 May 2017 / Accepted: 3 January 2018 / Published online: 17 January 2018

(C) The Author(s) 2018. This article is an open access publication

\begin{abstract}
In recent years, the production of eel larvae has dramatic declines due to reductions in spawning stocks, overfishing, growth habitat destruction and access reductions, and pollution. Therefore, it is particularly important and urgent for artificial production of glass eels. However, the technique of artificial hatching and rearing larvae is still immature, which has long been regarded as an extremely difficult task. One of the huge gaps is artificial condition which is far from the natural condition to develop their capability of osmoregulation. Thus, understanding their osmoregulatory mechanisms will help to improve the breed and adapt to the changes in the environment. In this paper, we give a general review for a study progress of osmoregulatory mechanisms in eels from five aspects including tissues and organs, ion transporters, hormones, proteins, and high throughput sequencing methods.
\end{abstract}

Keywords Anguillid eels · Catadromous migration . Osmoregulation · Ion transport

Q. Cao $\cdot$ D. Wang $\cdot$ F. Liang $\cdot$ H. Zhang $\cdot$ X. Li $\cdot$

S. Yin $(\bowtie)$

College of Life Sciences, Key Laboratory of Biodiversity and Biotechnology of Jiangsu Province, Nanjing Normal University, 1 Wenyuan Road, Nanjing, Jiangsu Province 210023, China e-mail: yinshaowu@163.com

J. Gu

Institute of Life Science, Jiangsu University, Zhenjiang, Jiangsu 212000, China

\section{Introduction}

Dramatic declines in glass eel recruitment of temperate species like the American (Anguilla rostrata), European (Anguilla anguilla), Japanese (Anguilla japonica), and Australian (Anguilla australis) eels have raised concerns (Côté et al. 2009; Harrison et al. 2014; Hoyle and Jellyman 2002). The reasons for the declines are unclear but are probably due to reductions in spawning stocks, overfishing, growth habitat and access reductions, pollution, swim bladder, gill parasites and viral infections, global climate change, and the solar cycle (Clevestam et al. 2011; Lin et al. 2010; Parker et al. 2008; Zenimoto et al. 2009). The drastic decline of recruiting wild glass eels has attracted much attention, so it has been increasing an urgent need for technology development in artificial seedlings production (Casselman 2003; Tanaka 2015; Unuma et al. 2012). Since the life history of the eel holds many mysteries, the artificial hatching and rearing of larvae has long been regarded as an extremely difficult task (Okamura et al. 2009; Unuma et al. 2004). The techniques of rearing leptocephalus larvae up to glass eels have been improved significantly in the laboratory, but these are still far from marketization (Celino et al. 2009; Okamura et al. 2014; Tanaka 2003; Tanaka 2014). To understand the artificial hatching and rearing of larvae, it is necessary to study physiological mechanism of osmoregulatory adaptation in anguillid eels.

The anguillid eels, as catadromous species, breed in the sea and migrate to grow near shore or freshwater habitats before returning to spawn in the sea. Therefore, it exhibits a remarkable ability to adapt its physiology as 
it transfers between seawater (SW, hyperosmotic) and freshwater (FW, hypoosmotic) environments (Maciver et al. 2009). In order to survive, it must completely shift its osmoregulatory system from the one in which excess salt is eliminated and water conserved (in SW), to the one in which the exact opposite is true (in FW). During the migratory process, how the osmotic pressure coordinates with the change of ion concentration to achieve the homeostasis is one of the important tasks in the research of genus Anguilla (Aarestrup et al. 2009; Morinière et al. 2002). Corresponding changes in salinity conditions affect the growth and development of eel (Gagnaire et al. 2009; Hu and Duan 2013). Changing ambient conditions will also influence the processing ability of osmotic pressure variation. Thus, it is particularly important to reveal the osmoregulation mechanism of eel and to increase the valuable theoretical basis in the research of genus Anguilla.

At present, scholars mainly focused on the osmotic regulation mechanism of anguillid eels and gained some important achievements in different aspects of the research. This article firstly introduces the osmoregulatory organs in the genus Anguilla, then presents the details of the osmotic regulation of ion transporters, hormones, proteins, and the transcriptomic and proteomic studies, and finally summarizes and reviews the research progress of osmotic regulation mechanism in recent years.

\section{Osmoregulatory tissues and organs}

Fishes obtain salts from food and ion absorption operating mainly in the gill, kidney, and intestine. (Hiroi et al. 2008; Martinez et al. 2005c; Saglam et al. 2013). These are important osmoregulatory tissues that function to maintain ion and water homeostasis as fish move between environments of wide ranging salinities (Comrie et al. 2001; Kültz 2015; Peh et al. 2009).

In both situations that eels are subjected to a high osmotic stress during migration from FW to SW, one of the major sites of water and ionic exchange between the internal milieu and the external environment are the gills (Lafont et al. 2006). The gill is a major site of passive ion and water movements owing to its large surface area and directly contract with the external environment (Mi et al. 2013; Miyoung 2009). At the same time, the gill is among the most important osmoregulatory organs because of the presence of pavement cells (PVC), mucus cells (MC), and various types of ion-transporting, mitochondrion-rich cells (MRC) (Catches et al. 2006; Girard and Payan 1980; Lai et al. 2015; Mizuhira et al. 1970). MRCs in the gills are the major site of ion absorption and secretion. There is consensus that MRCs maintain transcellular secretion of $\mathrm{Cl}^{-}$and establish the conditions for paracellular electrochemical diffusion of $\mathrm{Na}^{+}$, which are important in both FW and SW adaptation (Pelis et al. 2001; Perry 1997; Seo et al. 2013; Utida et al. 1971).

The renal sulfate transport system has dual roles in euryhaline eel, namely, maintenance of sulfate homeostasis and osmoregulation of body fluids (Nakada et al. 2005). The trunk kidney of teleosts is generally composed of numerous nephrons, acting as a functional unit for renal osmoregulation, and the infilling lymphoid tissues (Teranishi et al. 2013). In FW teleosts, the nephron consists of a renal corpuscle and proximal and distal renal tubules, followed by a collecting duct, whereas nephrons in SW teleosts typically lack the distal tubule (Akira et al. 2005; Teranishi 2010). In particular, the kidney plays a major role in euryhaline teleost such as eel as it helps in maintaining body fluid homeostasis during the course of adaptation to different salinities ( $\mathrm{Li}$ et al. 2015; Martinez et al. 2005a; Teranishi et al. 2013). The kidney is fully by glomerular functions as in any other euryhaline fish (Cliff and Beyenbach 1988; Kenyon et al. 1985; Teranishi 2010). In SW, the euryhaline fish kidney filters plasma at low rates to conserve water, and tubular secretion of electrolytes and fluid contribute significantly to urine formation, serving primarily as the main secretary route for absorbed $\mathrm{Mg}^{2+}$, $\mathrm{Ca}^{2+}$, and $\mathrm{SO}_{4}{ }^{2-}$ (Rajagopal and Wallace 2015). While in FW, the kidney filters at high rates and reabsorbs nearly all filtered solutes, thereby producing large volumes of dilute urine. In this way, the osmotic water loads of the FW habitat are excreted (Nishimura et al. 1983; Teranishi et al. 2013).

As for the intestine, it needs to cope with potential dehydration from the hyperosmotic seawater environment (Yuge and Takei 2007). Numerous $\mathrm{Na}^{+}-\mathrm{K}^{+}-2 \mathrm{Cl}^{-}$cotransporters (NKCCs) are located on the mucosal surface of the intestinal epithelia in SW fish for absorption of these three ions in parallel with water absorption from the intestinal lumen (Schettino and Lionetto 2003; Yuge and Takei 2007). It was well known that water was hardly absorbed in the stomach and intestine, and water absorption predominantly took place in the rectum. For example, the Japanese eel exert hyperosmotic ability as early as during leptocephalus stages, secreting $\mathrm{Na}^{+}$and 
$\mathrm{Cl}^{-}$through absorbing water from ingested seawater in the rectum (Lee et al. 2012).

Eels sometimes need to adjust saline pressure by nervous system (Hirano et al. 1972; Montero et al. 2010). While neural mechanisms through drinking play an essential role in body fluid balance in marine teleost fish, as the sole means to compensate for osmotic water loss (Hirano et al. 1972; Takei et al. 1979). Drinking behavior is integrated in the brain through several neuropeptides, which may centrally act in a paracrine/ autocrine fashion to regulate drinking peripheral hormones through structures devoid of the blood-brain barrier (Takei et al. 1979). In the eel, swallowing is coordinated by the glossopharyngeal and vagus nerves, which originate from the glossopharyngeal-vagal complex (GVC) located in the midbrain-hindbrain area of the brain (Mukuda 2003). The GVC is a motor nucleus controlling swallowing and regulating contraction of the upper esophageal sphincter (UES) muscle via the vagal nerve fibers (Kozaka and Ando 2003; Mukuda and Ando 2003). Therefore, there is a possibility that the relaxin-producing neurons identified in the midbrain and hindbrain send their axons to the GVC and regulate swallowing in eels (Hu et al. 2011). It has been shown that systemic injection of eel atrial natriuretic peptide acts on the area postrema in the eel hindbrain and potently inhibits drinking (Tsukada et al. 2007), and direct injection of adrenomedullins into the cerebral ventricle of eels induced drinking (Ogoshi et al. 2008).

\section{Ion transporter}

The basolateral sodium-potassium ATPase (NKA) concentrates $\mathrm{Na}^{+}$extracellularly, and sodium-potassiumchloride cotransporter (NKCC1) takes up $\mathrm{Cl}^{-}$from the serosal side; NKA concentrates $\mathrm{Na}^{+}$extracellularly, which builds up an electrochemical gradient to excrete $\mathrm{Na}^{+}$via a paracellular pathway while $\mathrm{Cl}^{-}$is excreted via apical CFTR transcellularly due to a lower intracellular voltage (Rajagopal and Wallace 2015). To be specific, NKA maintains the $\mathrm{Na}^{+}$gradient in the cell, which converts the NKCC to cotransport $\mathrm{Cl}^{-}$against its electrochemical gradient. The intracellular $\mathrm{Cl}^{-}$exits the cell via the apical CFTR channel down its electrochemical gradient (Hirose et al. 2003). The movements of essential ion, chloride, and sodium, are effected through a main enzyme, the NKA in these epithelium cells. It also coordinated with other ion channels and transporters, such as the NKCC, the $\mathrm{Na}^{+} / \mathrm{Cl}^{-}$cotransporter (NCC), and the CFTR chloride channel (Lorin-Nebel et al. 2006). Following various mechanisms according to models and salinity, these channels and transporters are involved in the exchanges of both chloride and sodium (NKCC/NCC), or chloride alone (CFTR), either for their uptake (hyper-regulation in fresh water) or excretion (hypo-regulation in seawater) (Hirose et al. 2003; Lorin-Nebel et al. 2006; Marshall 2002; Papadakis et al. 2013; Varsamos et al. 2005). $\mathrm{Na}^{+}$accumulated in the intercellular space exits across the tight junction between neighboring MRCs. In adult eels, the relationship between environmental salinity and branchial NKA has been firmly established at the cellular and molecular level (Wilson et al. 2007). In freshwater teleost fishes, NKA is involved in $\mathrm{Na}^{+}$uptake, although levels of activity tend to be lower than in those found in seawater fishes. Freshwater eels also actively take up $\mathrm{Na}^{+}$and $\mathrm{Cl}^{-}$, although at rates significantly lower than other teleosts (Kuroki et al. 2016). In some fishes, Myoxocephalus octodecemspinosus and Anguilla anguilla, a vacuolar type proton ATPase (V-ATPase) is involved in indirectly driving $\mathrm{Na}^{+}$uptake across the apical membrane via $\mathrm{Na}^{+}$channels by creating a favorable electrochemical gradient (Catches et al. 2006; Harvey 2009; Lorin-Nebel et al. 2013). In A. anguilla and Fundulus heteroclitus, sodium-proton exchangers (NHE) directly facilitate $\mathrm{Na}^{+}$uptake. The mechanism of $\mathrm{Na}^{+}$uptake in eels has not yet been identified (Cutler and Cramb 2008; Edwards et al. 2005).

The reabsorption of sulfate via the apical Slc13al and basolateral Slc26a1 transporters may thus contribute to freshwater osmoregulation in euryhaline eels, via the regulation of circulating sulfate concentration (Nakada et al. 2005). Slc13a1 is an electrogenic $\mathrm{Na}^{+}$-dependent sulfate transporter (alternatively called $\mathrm{Na}^{+}-\mathrm{SO}_{4}{ }^{2-}$ cotransporter) located in the apical membrane of renal proximal tubule cells and mediates entry of $\mathrm{Na}^{+}-\mathrm{SO}_{4}{ }^{2-}$ (Busch et al. 1994). Slc26al is sulfate/anion exchanger mediating $\mathrm{SO}_{4}{ }^{2-}$ efflux across the basolateral membrane in exchange for $\mathrm{HCO}_{3}{ }^{-}$ (Karniski et al. 1998). Taken together, the eel sulfate transport system, composed of apical Slc13a1 and basolateral Slc26a1, turn out to play dual roles under freshwater conditions: (1) to prevent sulfate loss and maintain sulfate homeostasis and (2) to accumulate and retain relatively high concentrations of sulfate as an osmolyte (Nakada 
et al. 2005). It explained not only the mechanism of maintaining sulfate homeostasis in freshwater but also why adult eels migrate to freshwater (Chadwick 1989).

\section{Hormone in osmoregulation}

In eels' reproductive migration, they undergo several physiological and morphological changes, including growth and differentiation of the olfactory system, which is believed to be crucial for navigation during migration and spawning (Westin 1990). In addition, there is an increase in plasma steroid levels, which in teleosts include both estrogens and androgens (Lokman et al. 1998; Sbaihi et al. 2010). The change of the external environment sets off the phenomenon of osmoregulation, which is, in teleosts, under a complex endocrine regulation, involving various hormones such as prolactin, growth hormone, cortisol (Mccormick 2001).

Hormones play an essential role in the regulation of ion and water balance in salinity transfer (Bradshaw and McCormick 2006). In teleosts, one of the major hormones is the corticosteroid that facilitates the processes for the successful acclimation of fish from FW to SW (Aruna et al. 2012b; Balm et al. 1989; Mccormick 2011). Cortisol is the major corticosteroid found in euryhaline teleost fish, with release from inter renal gland being stimulated as fish are transferred from FW into SW (Mccormick 2011; Teles et al. 2013). And it is also often referred to as a SW-adapting hormone, as it is heavily implicated in the ability of fish to maintain water and electrolyte balance when in the SW environment (Aruna et al. 2012a; Kammerer et al. 2010; Tokarz et al. 2013).

The action of this hormone has been reported to include improved water absorptive capacity in both the intestine and the urinary bladder, and increased NKA activity in the gill, which together enable the fish to hyperosmolality in the hypersaline environment (Dantzler 2003). Plasma cortisol levels are known to rise following the transfer of eels from $\mathrm{FW}$ to $\mathrm{SW}$, although the hormone's general role is complex, and its functions include the mediation of the response to several different types of stressors (Fenwick and Forster 1972; Li and Takei 2003). Cortisol infusions in FW eels are able to mimic the effect of $\mathrm{SW}$-acclimation on intestinal aquaporin 1 (AQP1) expression, or in the esophagus of silver eels (Martinez et al. 2005b; Martinez et al. 2005d).

Prolactin (PRL), growth hormone (GH), and somatolactin (SL) are pituitary hormones that control pleiotropic biological functions in teleosts and are originated from a common ancestral molecule (Rand and Swanson 1994 and Celis et al. 2004). Prolactin performs a variety of important functions in vertebrates, is known as the fresh water-adapting hormone in fish, and is also known to be essential for the successful acclimation of fish to FW (Manzon 2002). Elevations in plasma prolactin are positively correlated with salt absorption within the gill and water excretion in the kidney and processes essential for osmoregulation in hypotonic environments (Han et al. 2003; Park et al. 2008; Sudo et al. 2013a). Although this correlation has been known for many years, there is still very little information about the molecular mechanisms responsible for the initiation and maintenance of these physiological processes. Likewise, $\mathrm{GH}$ is also known to be a hormone required for SW adaptation, at least during the early stages of acclimation (Sakamoto and McCormick 2006). Although the actions of these hormones are linked to regulation of NKA and a number of other water and solute transporters, the molecular mechanisms responsible for these effects remain unknown. Moreover, GH regulates development and somatic growth and is involved as a hypoosmoregulatory hormone for seawater adaptation in fish (Sakamoto and McCormick 2006). In contrast, teleost PRL is regarded as a hyper-osmoregulatory hormone for freshwater adaptation (Breves et al. 2011; Eckert et al. 2001; Watanabe et al. 2016). SL is involved in energy mobilization, stress response, calcium metabolism, acidosis, and pigmentation in teleosts, although there is little information of its osmoregulatory functions (Kawauchi and Sower 2006; Sudo et al. 2013b).

In addition, the eel is a euryhaline, migratory species that reverses water and ion regulation when moving between FW and SW environments. One of the most profound changes in regulation is drinking, which increases dramatically when eels are transferred from FW to SW (Hirano 1974). Two major hormones in the eel regulate drinking such as angiotensin II and the natriuretic peptides, and their concentration increased mildly and transiently after SW transfer in blood volume (Okawara et al. 1987; Tsukada and Takei 2006). Relaxins (RLN3) was known as an intrinsic brain 
peptide that regulates arousal and motivation (Olucha-Bordonau et al. 2003), which also plays an important role in the regulation of drinking in teleost fish (Takei 2008).

\section{Other proteins in osmoregulation}

Water is exchanged through osmosis following ionic gradients, a movement that is facilitated by transmembrane proteins (aquaporins, AQPs) (GiffardMena et al. 2007; Lin et al. 2004). It is a major intrinsic protein/aquaporin family of plasma membrane channels, and these aquaglyceroporins are usually capable of transporting small solutes, such as glycerol and urea, as well as water (Gorelick et al. 2006). The effect of AQP3 was widely known on water transport in the kidney of vertebrates in general and of eels in particular, especially in association with migration to the SW environment (Kalujnaia et al. 2007b; Martinez et al. 2005a).

Guanylin, uroguanylin, and lympho-guanylin are members of a family of heat-stable peptides that mediate their actions via the guanylate cyclase receptor isoform termed GC-C (Cutler et al. 2007; Li et al. 2015), which is likely to play a major role in osmoregulation in both freshwater and marine teleosts (Comrie et al. 2001). The major function of guanylin is regulation of water and electrolytes (particularly $\mathrm{Cl}^{-}$) transport of the intestine, and uroguanylin also participates in renal handling of water and electrolytes (Yuge et al. 2003). Guanylins are synthesized locally in the intestine and secreted into the lumen to act on the GC-Cs in the apical membrane of eel intestinal cells. Then, intracellular cGMP produces after ligand-receptor interaction activates CFTR and probably induces $\mathrm{Cl}^{-}$and/or $\mathrm{HCO}_{3}{ }^{-}$secretion into the lumen as suggested in mammals. The physiological significance of the anion secretion induced by the luminal guanylin/GC-C system on SW adaptation may rival or exceed that of the serosally derived natriuretic peptides in the euryhaline eel (Takei and Yuge 2007).

The members of the cation-chloride-cotransporter (CCC) gene family are most closely associated with the processes of $\mathrm{Na}$ and $\mathrm{Cl}$ ion absorption in epithelia, such as $\mathrm{Na}^{+} / \mathrm{K}^{+} / \mathrm{Cl}^{-}$cotransporter, NKCC2 and the $\mathrm{Na}^{+} / \mathrm{Cl}^{-}$cotransporter (NCC) (Hoffmann et al. 2007). These two cotransporters are expressed almost exclusively in the thick ascending loop of Henle and the distal convoluted tubule of the kidney respectively and play major roles in $\mathrm{NaCl}$ reabsorption during urine formation. The main role of the postulated NKCC2-like $\mathrm{Na}^{+} / \mathrm{K}^{+} / \mathrm{Cl}^{-}$cotransporter in eel fish is to absorb ions from imbibed seawater in the intestinal lumen, which result primarily from an osmoregulatory drinking response. The NKCC2-like cotransporter is consequently thought to be present in the apical brush-border membrane of the tall columnar surface epithelial cells of the intestine, where it carries a significant proportion of the sodium, potassium, and chloride ions absorbed from the lumen, into these cells (Ando et al. 2003; Cutler and Cramb 2008). In renal tubules and collecting ducts, $\mathrm{Na}^{+}$and $\mathrm{Cl}^{-}$are reabsorbed from primitive urine through $\mathrm{Na}^{+} / \mathrm{H}^{+}$exchanger 3 (NHE3) in the proximal tubule, $\mathrm{Na}^{+}-\mathrm{K}^{+}-2 \mathrm{Cl}^{-}$cotransporter 2 (NKCC2) in the thick ascending limb of Henle's loop, $\mathrm{Na}^{+}-\mathrm{Cl}^{-}$ cotransporter (NCC) in the distal convoluted tubule, and epithelial $\mathrm{Na}^{+}$channel $(\mathrm{ENaC})$ in the collecting duct (Pochynyuk et al. 2008). Tse et al. demonstrated the effect of osmotic shrinkage that stimulated cell regulatory volume increase (RVI) as well as the expressions of the three important ion transporters: $\mathrm{Na}^{+} / \mathrm{K}^{+}$-ATPase, $\mathrm{Na}^{+} / \mathrm{K}^{+} / 2 \mathrm{Cl}^{-}$cotransporter (NKCC), and $\mathrm{Na}^{+} / \mathrm{H}^{+}$exchanger-1 (NHE-1) using purified pavement cells (PVCs) (Tse et al. 2006).

\section{High throughput sequencing method applied in osmoregulation of eel}

The application of transcriptomics to the biology of eels can provide a significant increase in basic information making it a powerful tool to enable basic and applied research. High throughput sequencing technologies provide new options to characterize transcriptomes and drive the development of new molecular tools and ultimately leading to a better understanding of the biology of the species (Baillon et al. 2015; Coppe et al. 2010; Gu et al. 2015; Henkel et al. 2012; Minegishi et al. 2012; Natasha et al. 2009; Ohara 2009). With the recent advancements of deep sequencing technology, the generation of transcriptome data is fast and comprehensive, which greatly facilitates the applications of functional genomics (Shokralla et al. 2012; Vera et al. 2008). In 2010, the first transcriptomic study through deep sequencing was performed on gill of A. anguilla (Coppe et al. 
2010). Utilization of transcriptomic sequencing gave insights into the osmoregulation mechanism, providing transcriptomic view of A. japonica catadromous behavior. This annotation provides information of the coding regions of the genes supported by transcriptome. The derived homologous evidences pave the way for phylogenetic analysis of important genetic traits and the improvement of the genome assembly (Liu et al. 2016).

In addition to transcriptome analysis, it is also important to conduct proteomic studies since it is proteins, rather than mRNA, that carry out biological functions (Tomanek 2011). Besides, posttranslation modifications such as phosphorylation cannot be determined by mRNA analysis. Recently developed proteomic techniques, such as isobaric tag for relative and absolute quantization (iTRAQ), can provide more reliable quantitative measurements and comparisons among samples than traditional two dimensional electrophoresis (2DE) analysis in Japanese eel (Tse et al. 2015). Moreover, iTRAQ analysis allows identification of more proteins than previous 2-DE proteomics and more reliable quantification of the proteins. Producing a sufficient number of proteins makes it possible to conduct pathway and protein-protein interaction analysis (Wang and You 2012). To be specific, in Anguilla japonica, Tse et al. had identified 19 gill proteins that respond to short-term hyperosmotic stress. Together with the protein-protein interaction network analysis, the study revealed the potential importance of the NFKB pathway in osmoregulation (Tse et al. 2013). In A. marmorata, Jia et al. detected a large number of differentially expressed proteins by iTRAQ method and a variety of miRNAs with a significant difference between two salinity levels (BW and SW), either in upregulation or downregulation status. These proteins enriched in different GO terms and KEGG pathways suggest the different mechanisms for the acclimation of juvenile eels to brackish water and seawater (Jia et al. 2016; Wang et al. 2015).

By combining the recent technological and methodological advances in transcriptomic and proteomic analysis, this genome wide study aims to identify specific eel gill proteins that play roles in acute FW to SW transfer. Furthermore, the microarray technique for salinity acclimation studies using known genes previously implicated in osmoregulation including prolactin, growth hormone, the $\mathrm{Na}^{+}, \mathrm{K}^{+}, 2 \mathrm{Cl}^{-}$cotransporter, and the $\mathrm{Na}^{+} / \mathrm{K}^{+}$-ATPase; and then also to report some unknown genes, the role of which in osmoregulation remains to be elucidated (Kalujnaia et al. 2007a).

\section{Conclusions and future perspective}

Like zebrafish, the eel belongs to the lower teleostei which are more primitive than pufferfish and medaka, two species of Percomorpha. In this study, we chose eels as a model species because they are euryhaline with excellent osmoregulatory ability, and various experimental techniques had been established in this species for physiological studies (Tsuchida and Takei 1998).

Euryhalinity and environmental stress tolerance are physiological traits that enable eels to complete their life cycle in variable habitats of fluctuating salinity. By contrast, Stenohaline fish, such as common carp, inhabiting osmotically stable environments (the oceans or freshwater lakes and streams) (Kültz 2015). So a wide physiological salinity tolerance range makes eels to have a much stronger trait and complicated function to adapt to high salinity stress. Many ion transporters, hormones, and proteins are involved in salinity stress tolerance, and they compete for the crowded cell interior and for energy resources supporting their synthesis and stabilization.

Some questions are still worth thinking about. Some gene isoforms have tissue-specific or organspecific expression pattern, which kind of functions they act? There would still more ion channel genes to be cloned in eels compared to mammals. What is more, the application of the knowledge about candidate genes is currently hampered by the lack of understanding of their functions at cell, tissue, and whole-fish levels.

Additionally, no studies examined naturally transfers from a hypersaline condition to either seawater or freshwater. These types of transfers should be explored. Since few studies that examined intraspecific variation in gene expression focused on teleosts, it needs further studies to be expanded in general. Finally, few studies examined gene expression in wild-caught animals, although some were not included because a reasonable approximation of time since transfer could not be estimated. Such a trend calls for better understanding of the 
biochemical and physiological mechanisms that enable eels to cope with large salinity fluctuations and extreme salinities.

Funding information This study was supported by the Natural science of Jiangsu Province (BK20141450), the National Natural Science Foundation of China (30770283), and the Project Foundation of the Academic Program Development of Jiangsu Higher Education Institution (PAPD).

Open Access This article is distributed under the terms of the Creative Commons Attribution 4.0 International License (http:// creativecommons.org/licenses/by/4.0/), which permits unrestricted use, distribution, and reproduction in any medium, provided you give appropriate credit to the original author(s) and the source, provide a link to the Creative Commons license, and indicate if changes were made.

\section{References}

Aarestrup K, Okland F, Hansen MM, Righton D, Gargan P, Castonguay M, Bernatchez L, Howey P, Sparholt H, Pedersen MI (2009) Oceanic spawning migration of the European eel (Anguilla anguilla). Science 325(5948):1660. https://doi.org/10.1126/science. 1178120

Akira K, Hiroyuki D, Tsutomu N, Harumi S, Shigehisa H (2005) Takifugu obscurusis a euryhaline fugu species very close to Takifugu rubripesand suitable for studying osmoregulation. BMC Physiol 5:18

Ando M, Mukuda T, Kozaka T (2003) Water metabolism in the eel acclimated to sea water: from mouth to intestine. Comp Biochem Phys B 136:621-633

Aruna A, Nagarajan G, Chang CF (2012a) Differential expression patterns and localization of glucocorticoid and mineralocorticoid receptor transcripts in the osmoregulatory organs of tilapia during salinity stress. Gen Comp Endocr 179(3):465476. https://doi.org/10.1016/j.ygcen.2012.08.028

Aruna A, Nagarajan G, Chang CF (2012b) Involvement of corticotrophin-releasing hormone and corticosteroid receptors in the brain-pituitary-gill of tilapia during the course of seawater acclimation. J Neuroendocrinol 24(5):818-830. https://doi.org/10.1111/j.1365-2826.2012.02282.x

Baillon L, Pierron F, Coudret R, Normendeau E, Caron A, Peluhet L, Labadie P, Budzinski H, Durrieu G, Sarraco J (2015) Transcriptome profile analysis reveals specific signatures of pollutants in Atlantic eels. Ecotoxicology 24(1):71-84. https://doi.org/10.1007/s10646-014-1356-x

Balm PHM, Lambert JDG, Bonga SEW (1989) Corticosteroid biosynthesis in the interrenal cells of the teleost fish, Oreochromis mossambicus. Gen Comp Endocr 76(1):5362. https://doi.org/10.1016/0016-6480(89)90032-4

Bradshaw D, McCormick S (2006) Hormonal control of salt and water balance in vertebrates - a symposium. Gen Comp Endocr 147(1):1-2. https://doi.org/10.1016/j. ygcen.2005.09.024

Breves JP, Seale AP, Helms RE, Tipsmark CK, Hirano T, Grau EG (2011) Dynamic gene expression of GH/PRL-family hormone receptors in gill and kidney during freshwateracclimation of Mozambique tilapia. Comp Biochem Phys A 158:194-200

Busch AE, Waldegger S, Herzer T, Biber J, Markovich D, Murer $\mathrm{H}$, Lang F (1994) Electrogenic cotransport of $\mathrm{Na}^{+}$and sulfate in Xenopus-oocytes expressing the cloned $\mathrm{Na}^{+} / \mathrm{SO}_{4}{ }^{2-}$ transport protein Nasi-1. J Biol Chem 269:12407

Côté CL, Castonguay M, Verreault G, Bernatchez L (2009) Differential effects of origin and salinity rearing conditions on growth of glass eels of the American eel Anguilla rostrata: implications for stocking programmes. J Fish Biol 74(9): 1934-1948. https://doi.org/10.1111/j.10958649.2009.02291.x

Casselman JM (2003) Dynamics of resources of the American eel, Anguilla rostrata: declining abundance in the 1990s. Eel Bio 2003:255-274

Catches JS, Burns JM, Edwards SL, Claiborne JB (2006) $\mathrm{Na}^{+} / \mathrm{H}^{+}$ antiporter, $\mathrm{V}-\mathrm{H}^{+}$-ATPase and $\mathrm{Na}^{+} / \mathrm{K}^{+}$-ATPase immunolocalization in a marine teleost (Myoxocephalus octodecemspinosus). J Exp Biol 209(17):3440-3447. https://doi.org/10.1242/jeb.02384

Celino FT, Yamaguchi S, Miura C, Miura T (2009) Arsenic inhibits in vitro spermatogenesis and induces germ cell apoptosis in Japanese eel (Anguilla japonica). Reproduction 138(2):279-287. https://doi.org/10.1530/REP-09-0167

Celis VRD, Rojas P, Gómez-Requeni P, Albalat A, Gutiérrez J, Médale F. (2004) Nutritional assessment of somatolactin function in gilthead sea bream (Sparus aurata). International Symposium on Fish Endocrinology

Chadwick EMP (1989) Diadromy in fishes: migrations between freshwater and marine environments by R. M. McDowall. The Quarterly Review of Biol 39

Clevestam PD, Ogonowski M, Sjöberg NB, Wickström H (2011) Too short to spawn? Implications of small body size and swimming distance on successful migration and maturation of the European eel Anguilla anguilla. J Fish Biol 78(4): 1073-1089. https://doi.org/10.1111/j.10958649.2011.02920.x

Cliff WH, Beyenbach KW (1988) Fluid secretion in glomerular renal proximal tubules of freshwater-adapted fish. Am J Physiol-Cell PH 254:154-158

Comrie MM, Cutler CP, Cramb G (2001) Cloning and expression of Guanylin from the European eel (Anguilla anguilla). Biochem Bioph Res Co 281(5):1078-1085. https://doi. org/10.1006/bbrc.2001.4485

Coppe A, Pujolar JM, Maes GE, Larsen PF, Hansen MM, Bernatchez L, Zane L, Bortoluzzi S (2010) Sequencing, de novo annotation and analysis of the first Anguilla anguilla transcriptome: EeelBase opens new perspectives for the study of the critically endangered European eel. BMC Genomics 11(1):635. https://doi.org/10.1186/1471-2164-11635

Cutler CP, Cramb G (2008) Differential expression of absorptive cation-chloride-cotransporters in the intestinal and renal tissues of the European eel (Anguilla anguilla). Comp Biochem Phys B 149:63-73

Cutler CP, Phillips C, Hazon N, Cramb G (2007) Cortisol regulates eel (Anguilla anguilla) aquaporin 3 (AQP3) mRNA expression levels in gill. Gen Comp Endocr 152(2-3):310-313. https://doi.org/10.1016/j.ygcen.2007.01.031 
Dantzler WH (2003) Regulation of renal proximal and distal tubule transport: sodium, chloride and organic anions. Comp Biochem Phys A 136:453-478

Eckert SM, Yada T, Shepherd BS, Stetson MH, Hirano T, Grau EG (2001) Hormonal control of osmoregulation in the channel catfish Ictalurus punctatus. Gen Comp Endocr 122(3):270286. https://doi.org/10.1006/gcen.2001.7633

Edwards SL, Wall BP, Morrison-Shetlar A, Sligh S, Weakley JC, Claiborne JB (2005) The effect of environmental hypercapnia and salinity on the expression of NHE-like isoforms in the gills of a euryhaline fish (Fundulus heteroclitus). J Exp Zool Part A 303:464-475

Fenwick JC, Forster ME (1972) Effects of stanniectomy and hypophysectomy on total plasma cortisol levels in the eel ( Anguilla anguilla L). Gen Comp Endocr 19(1):184-191. https://doi.org/10.1016/0016-6480(72)90019-6

Gagnaire PA, Minegishi Y, Aoyama J, Réveillac E, Robinet T, Bosc P, Tsukamoto K, Feunteun E, Berrebi P (2009) Ocean currents drive secondary contact between Anguilla marmorata populations in the Indian Ocean. Mar Ecol-Prog Ser 379:267-278

Giffard-Mena I, Boulo V, Aujoulat F, Fowden H, Castille R, Charmantier G, Cramb G (2007) Aquaporin molecular characterization in the sea-bass (Dicentrarchus labrax): the effect of salinity on AQP1 and AQP3 expression. Comp Biochem Phys A 148:430-444

Girard JP, Payan P (1980) Ion exchanges through respiratory and chloride cells in freshwater- and seawater-adapted teleosteans. Am J Physiol-Cell PH 238:R260

Gorelick DA, Praetorius J, Tsunenari T, Nielsen S, Agre P (2006) Aquaporin-11: a channel protein lacking apparent transport function expressed in brain. BMC Biochem 7(1):14. https://doi.org/10.1186/1471-2091-7-14

Gu J, Li JW, Tse WK, Chan TF, Lai KP, Wong CK (2015) Transcriptomic responses of corpuscle of Stannius gland of Japanese eels (Anguilla japonica) to changes in water salinity[J]. SCI Rep-UK, 2015 5(7):9836

Han YS, Yu J, Liao IC, Tzeng WN (2003) Salinity preference of silvering Japanese eel Anguilla japonica: evidence from pituitary prolactin mRNA levels and otolith $\mathrm{Sr}: \mathrm{Ca}$ ratios. Mar Ecol-Prog Ser 259:253-261

Harrison AJ, Walker AM, Pinder AC, Briand C, Aprahamian MW (2014) A review of glass eel migratory behaviour, sampling techniques and abundance estimates in estuaries: implications for assessing recruitment, local production and exploitation. Rev Fish Biol Fisher 24(4):967-983. https://doi. org/10.1007/s11160-014-9356-8

Harvey WR (2009) Voltage coupling of primary $\mathrm{H}^{+}$-V-ATPases to secondary $\mathrm{Na}^{+}$- or $\mathrm{K}^{+}$-dependent transporters. J Exp Biol 212(11):1620-1629. https://doi.org/10.1242/jeb.031534

Henkel CV, Dirks RP, de Wijze DL, Minegishi Y, Aoyama J, Jansen HJ, Turner B, Knudsen B, Bundgaard M, Hvam KL (2012) First draft genome sequence of the Japanese eel, Anguilla japonica. Gene 511(2):195-201. https://doi. org/10.1016/j.gene.2012.09.064

Hirano T (1974) Some factors regulating water intake by the eel, Anguilla japonica. J Exp Biol 61(3):737-747

Hirano T, Satou M, Utida S (1972) Central nervous system control of osmoregulation in the eel (Anguilla japonica). Comp Biochem Phys A 43:537-544
Hiroi J, Yasumasu S, Mccormick SD, Hwang PP, Kaneko T (2008) Evidence for an apical $\mathrm{Na}-\mathrm{Cl}$ cotransporter involved in ion uptake in a teleost fish. J Exp Biol 211(16):2584-2599. https://doi.org/10.1242/jeb.018663

Hirose S, Kaneko T, Naito N, Takei Y (2003) Molecular biology of major components of chloride cells. Comp Biochem Phys B 136:593-620

Hoffmann EK, Schettino T, Marshall WS (2007) The role of volume-sensitive ion transport systems in regulation of epithelial transport. Comp Biochem Phys A 148:29-43

Hoyle SD, Jellyman DJ (2002) Longfin eels need reserves: modelling the effects of commercial harvest on stocks of New Zealand eels. Mar Freshw Res 53(5):887-895. https://doi. org/10.1071/MF00020

Hu GB, Kusakabe M, Takei Y (2011) Localization of diversified relaxin gene transcripts in the brain of eels. Gen Comp Endocr 172(3):430-439. https://doi.org/10.1016/j. ygcen.2011.04.013

Hu ZM, Duan DL (2013) Insufficient geographical sampling could severely influence phylogeographic interpretations. Mar Biol 160(6):1521-1522. https://doi.org/10.1007 /s00227-013-2198-4

Jia Y, Yin S, Li L, Li P, Liang F, Wang X, Wang L, Su X (2016) iTRAQ proteomic analysis of salinity acclimation proteins in the gill of tropical marbled eel (Anguilla marmorata). Fish Physiol Biochem 42(3):935-946. https://doi.org/10.1007 /s10695-015-0186-y

Kültz D (2015) Physiological mechanisms used by fish to cope with salinity stress. J Exp Biol 218(12):1907-1914. https://doi.org/10.1242/jeb.118695

Kalujnaia S, Mcwilliam IS, Zaguinaiko VA, Feilen AL, Nicholson J, Hazon N, Cutler CP, Balment RJ, Cossins AR, Hughes M (2007a) Salinity adaptation and gene profiling analysis in the European eel (Anguilla anguilla) using microarray technology. Gen Comp Endocr 152(2-3):274-280. https://doi. org/10.1016/j.ygcen.2006.12.025

Kalujnaia S, McWilliam IS, Zaguinaiko VA, Feilen AL, Nicholson J, Hazon N, Cutler CP, Balment RJ, Cossins AR, Hughes M, Cramb G (2007b) Salinity adaptation and gene profiling analysis in the European eel (Anguilla anguilla) using microarray technology. Gen Comp Endocr 152(2-3):274-280. https://doi.org/10.1016/j.ygcen.2006.12.025

Kammerer BD, Cech JJ Jr, Kultz D (2010) Rapid changes in plasma cortisol, osmolality, and respiration in response to salinity stress in tilapia (Oreochromis mossambicus). Comp Biochem Phys A 157:260-265

Karniski LP, Lötscher M, Fucentese M, Hilfiker H, Biber J, Murer H (1998) Immunolocalization of sat-1 sulfate/oxalate/bicarbonate anion exchanger in the rat kidney. Am J Physiol-Cell PH 275(1):F79-F87. https://doi.org/10.1152 /ajprenal.1998.275.1.F79

Kawauchi H, Sower SA (2006) The dawn and evolution of hormones in the adenohypophysis. Gen Comp Endocr 148(1):314. https://doi.org/10.1016/j.ygcen.2005.10.011

Kenyon CJ, Mckeever A, Oliver JA, Henderson IW (1985) Control of renal and adrenocortical function by the reninangiotensin system in two euryhaline teleost fishes. Gen Comp Endocr 58(1):93-100. https://doi.org/10.1016/00166480(85)90140-6 
Kozaka T, Ando M (2003) Cholinergic innervation to the upper esophageal sphincter muscle in the eel, with special reference to drinking behavior. J Comp Physiol B 173:135

Kuroki M, Seo MY, Okamura A, Watanabe S, Tsukamoto K, Kaneko T (2016) Morphofunctional features of ionocytes in Japanese eel Anguilla japonica leptocephali acclimated to half-diluted and full-strength seawater. Ichthyol Res 63(4): 487-495. https://doi.org/10.1007/s10228-016-0520-0

Lafont AG, Fitzpatrick T, Rankin JC, Dufour S, Fouchereau-Peron $M$ (2006) Possible role of calcitonin gene-related peptide in osmoregulation via the endocrine control of the gill in a teleost, the eel, Anguilla anguilla. Peptides 27(4):812-819. https://doi.org/10.1016/j.peptides.2005.09.009

Lai KP, Li JW, Gu J, Chan TF, Tse WKF, Wong CKC (2015) Transcriptomic analysis reveals specific osmoregulatory adaptive responses in gill mitochondria-rich cells and pavement cells of the Japanese eel. BMC Genomics 16(1):1072. https://doi.org/10.1186/s12864-015-2271-0

Lee KM, Yamada Y, Okamura A, Tsukamoto K, Kaneko T (2012) Hyposmoregulatory ability and ion- and water-regulatory mechanisms during the leptocephalus stages of Japanese eel Anguilla japonica. Fish Sci 79:77-86

Li L, Jia Y, Li P, Yin S, Zhang G, Wang X, Wang Y, Wang X, Zang $\mathrm{X}$, Ding Y (2015) Expression and activity of $\mathrm{V}_{-} \mathrm{H}^{+}$-ATPase in gill and kidney of marbled eel Anguilla marmorata in response to salinity challenge. J Fish Biol 87(1):28-42. https://doi.org/10.1111/jfb.12687

Li YY, Takei Y (2003) Ambient salinity-dependent effects of homologous natriuretic peptides (ANP, VNP, and CNP) on plasma cortisol level in the eel. Gen Comp Endocr 130(3): 317-323. https://doi.org/10.1016/S0016-6480(02)00640-8

Lin CH, Huang CL, Yang CH, Lee TH, Hwang PP (2004) Timecourse changes in the expression of $\mathrm{Na}^{+}, \mathrm{K}^{+}$-ATPase and the morphometry of mitochondrion-rich cells in gills of euryhaline tilapia (Oreochromis mossambicus) during freshwater acclimation. J Exp Zool Part A 301:85-96

Lin YJ, Chang YJ, Sun CL, Tzeng WN (2010) Evaluation of the Japanese eel fishery in the lower reaches of the Kao-Ping River, southwestern Taiwan using a per-recruit analysis. Fish Res 106(3):329-336. https://doi.org/10.1016/j. fishres.2010.08.015

Liu YC, Hsu SD, Chou CH, Huang WY, Chen YH, Liu CY, Lyu GJ, Huang SZ, Aganezov S, Alekseyev MA et al (2016) Transcriptome sequencing based annotation and homologous evidence based scaffolding of Anguilla japonica draft genome. BMC Genomics 17(Suppl 1):13

Lokman PM, Vermeulen GJ, Lambert JGD, Young G (1998) Gonad histology and plasma steroid profiles in wild New Zealand freshwater eels (Anguilla dieffenbachii and A. australis) before and at the onset of the natural spawning migration. I. Females. Fish Physiol Biochem 19(4):325-338. https://doi.org/10.1023/A:1007719414295

Lorin-Nebel C, Boulo V, Bodinier C, Charmantier G (2006) The $\mathrm{Na}^{+} / \mathrm{K}^{+} / 2 \mathrm{Cl}^{-}$cotransporter in the sea bass Dicentrarchus labrax during ontogeny: involvement in osmoregulation. $\mathrm{J}$ Exp Biol 209(24):4908-4922. https://doi.org/10.1242 /jeb.02591

Lorin-Nebel C, Felten V, Blondeau-Bidet E, Grousset E, Amilhat E, Simon G, Biagianti S, Charmantier G (2013) Individual and combined effects of copper and parasitism on osmoregulation in the European eel Anguilla anguilla. Aquat Toxicol
$130-131: 41-50$. https://doi.org/10.1016/j. aquatox.2012.11.018

Maciver B, Cutler CP, Yin J, Hill MG, Zeidel ML, Hill WG (2009) Expression and functional characterization of four aquaporin water channels from the European eel (Anguilla anguilla). J Exp Biol 212(17):2856-2863. https://doi.org/10.1242 /jeb.025882

Manzon LA (2002) The role of prolactin in fish osmoregulation: a review. Gen Comp Endocr 125(2):291-310. https://doi. org/10.1006/gcen.2001.7746

Marshall WS (2002) $\mathrm{Na}^{+}, \mathrm{cl}^{-}, \mathrm{Ca}^{2+}$ and $\mathrm{Zn}^{2+}$ transport by fish gills: retrospective review and prospective synthesis. J Exp Zool 293(3):264-283. https://doi.org/10.1002/jez.10127

Martinez AS, Cutler CP, Wilson GD, Phillips C, Hazon N, Cramb $\mathrm{G}$ (2005a) Cloning and expression of three aquaporin homologues from the European eel (Anguilla anguilla): effects of seawater acclimation and cortisol treatment on renal expression. Biol Cell 97(8):615-627. https://doi.org/10.1042 /BC20040111

Martinez AS, Cutler CP, Wilson GD, Phillips C, Hazon N, Cramb $\mathrm{G}$ (2005b) Regulation of expression of two aquaporin homologs in the intestine of the European eel: effects of seawater acclimation and cortisol treatment. Am J Physiol-Reg I 288: R1733-R1743

Martinez AS, Cutler CP, Wilson GD, Phillips C, Hazon N, Cramb $\mathrm{G}(2005 \mathrm{c})$ Regulation of expression of two aquaporin homologs in the intestine of the European eel: effects of seawater acclimation and cortisol treatment. Am J Physiol Regul Integr Comp Physiol 288(6):R1733-R1743. https://doi. org/10.1152/ajpregu.00747.2004

Martinez AS, Wilson G, Phillips C, Cutler C, Hazon N, Cramb G (2005d) Effect of cortisol on aquaporin expression in the esophagus of the European eel, Anguilla anguilla. Ann N Y Acad Sci 1040(1):395-398. https://doi.org/10.1196 /annals.1327.072

Mccormick SD (2001) Endocrine control of osmoregulation in teleost fish. Am Zool 41:781-794

Mccormick SD (2011) The hormonal control of osmoregulation in teleost fish. In: Farrell AP (ed) Encyclopedia of fish physiology: from genome to environment. Academic Press, San Diego, pp 1466-1473. https://doi.org/10.1016/B978-0-12374553-8.00212-4

Mi YS, Mekuchi M, Teranishi K, Kaneko T (2013) Expression of ion transporters in gill mitochondrion-rich cells in Japanese eel acclimated to a wide range of environmental salinity. Comp Biochem Phys A 166:323

Minegishi Y, Henkel CV, Dirks RP, Ge VDT (2012) Genomics in eels - towards aquaculture and biology. Mar Biotechnol 14(5):583-590. https://doi.org/10.1007/s10126-012-9444-5

Miyoung S (2009) Morphological changes in gill mitochondriarich cells in cultured Japanese eel Anguilla japonica acclimated to a wide range of environmental salinity. Fisheries SCI 75:1147-1156

Mizuhira V, Amakawa T, Yamashina S, Shirai N, Utida S (1970) Electron microscopic studies on the localization of sodium ions and sodium-potassium-activated adenosinetriphosphatase in chloride cells of eel gills. Eep Cell Res 59(2):346-348. https://doi.org/10.1016/0014-4827 (70)90613-0

Montero M, Yon L, Rousseau K, Arimura A, Fournier A, Dufour S, Vaudry H (2010) Localization of pituitary adenylate 
cyclase-activating polypeptide in the central nervous system of the European eel Anguilla anguilla: stimulatory effect of PACAP on GH secretion. Ann N Y Acad Sci 865:475-477

Morinière ECDL, Pollux BJA, Nagelkerken I, Velde GVD (2002) Post-settlement life cycle migration patterns and habitat preference of coral reef fish that use seagrass and mangrove habitats as nurseries. Estuar Coast Shelf S 55(2):309-321. https://doi.org/10.1006/ecss.2001.0907

Mukuda T, Ando M (2003) Medullary motor neurones associated with drinking behaviour of Japanese eels. J Fish Biol 62(1): 1-12. https://doi.org/10.1046/j.1095-8649.2003.00002.x

Mukuda T, MA (2003) Brain Atlas of the Japanese eel: comparison to other fishes. Sci Rep 29

Nakada T, Zandinejad K, Kurita Y, Kudo H, Broumand V, Kwon CY, Mercado A, Mount DB, Hirose S (2005) Roles of Slc13al and Slc26al sulfate transporters of eel kidney in sulfate homeostasis and osmoregulation in freshwater. Am J Physiol-Reg I 289:R575-R585

Natasha L, Olaf K, Antonio C, Alberto F, Diana B, Pascal B, Massimo D (2009) Combining next-generation pyrosequencing with microarray for large scale expression analysis in non-model species. BMC Genomics 10:1-9

Nishimura H, Imai M, Ogawa M (1983) Sodium chloride and water transport in the renal distal tubule of the rainbow trout. Am J Physiol-Cell PH 244(3):F247-F254. https://doi. org/10.1152/ajprenal.1983.244.3.F247

Ogoshi M, Nobata S, Takei Y (2008) Potent osmoregulatory actions of homologous adrenomedullins administered peripherally and centrally in eels. Am J Physiol-Reg I 295: R2075

Ohara O (2009) From transcriptome analysis to immunogenomics: current status and future direction. FEBS Lett 583(11):16621667. https://doi.org/10.1016/j.febslet.2009.04.021

Okamura A, Horie N, Mikawa N, Yamada Y, Tsukamoto K (2014) Recent advances in artificial production of glass eels for conservation of anguillid eel populations. Ecol Freshw Fish 23(1):95-110. https://doi.org/10.1111/eff.12086

Okamura A, Yamada Y, Horie N, Mikawa N, Utoh T, Tanaka S, Tsukamoto K (2009) Toxicity and antibacterial activity of silver ions in the rearing water of Japanese eel eggs and larvae. Nippon Suisan Gakk 75(5):786-792. https://doi. org/10.2331/suisan.75.786

Okawara Y, Karakida T, Aihara M, Yamaguchi KI, Kobayashi H (1987) Involvement of angiotensin II in water intake in the Japanese eel, Anguilla japonica: endocrinology. Zool Sci 4: $523-528$

Olucha-Bordonau FE, Teruel V, Barcia-González J, Ruiz-Torner A, Valverde-Navarro AA, Martínez-Soriano F (2003) Cytoarchitecture and efferent projections of the nucleus incertus of the rat. J Comp Neurol 464(1):62-97. https://doi.org/10.1002/cne.10774

Papadakis IE, Kentouri M, Divanach P, Mylonas CC (2013) Ontogeny of the digestive system of meagre Argyrosomus regius reared in a mesocosm, and quantitative changes of lipids in the liver from hatching to juvenile. Aquaculture 388$391: 76-88$. https://doi.org/10.1016/j. aquaculture.2013.01.012

Park, W. D., Lee, C. H., Kim, D. J., and Sohn, Y. C. (2008). Changes in prolactin and growth hormone gene expression in three freshwater teleosts with rapid changes in salinity. Fish. Soc 2008, 41(1):1-6
Parker D, Weyl OLF, Taraschewski H (2008) Invasion of a south African Anguilla mossambica (Anguillidae) population by the alien gill worm Pseudodactylogyrus anguillae (Monogenea). Afr Zool 46:371-377

Peh WYX, Chew SF, Wilson JM, Ip YK (2009) Branchial and intestinal osmoregulatory acclimation in the four-eyed sleeper, Bostrychus Sinensis (Lacepède), exposed to seawater. Mar Biol 156(9):1751-1764. https://doi.org/10.1007 /s00227-009-1210-5

Pelis RM, Zydlewski J, Mccormick SD (2001) Gill Na( $\left(^{+}\right)-\mathrm{K}\left({ }^{+}\right)$$2 \mathrm{Cl}\left({ }^{\circ}\right)$ cotransporter abundance and location in Atlantic salmon: effects of seawater and smolting. Am J Physiol-Reg I 280:R1844

Perry SF (1997) The chloride cell: structure and function in the gills of freshwater fishes. Annu Rev Physiol 59(1):325-347. https://doi.org/10.1146/annurev.physiol.59.1.325

Pochynyuk O, Bugaj V, Rieg T, Insel PA, Mironova E, Vallon V, Stockand JD (2008) Paracrine regulation of the epithelial $\mathrm{Na}^{+}$ channel in the mammalian collecting duct by purinergic P2Y2 receptor tone. The J Biol Chem 283(52):3659936607. https://doi.org/10.1074/jbc.M807129200

Rajagopal M, Wallace DP (2015) Chloride secretion by renal collecting ducts. Curr Opin Nephrol Hy 24(5):444-449. https://doi.org/10.1097/MNH.0000000000000148

Rand-Weaver M, Swanson P (1994) Plasma somatolactin levels in coho salmon (Oncorhynchus kisutch) during smoltification and sexual maturation. Fish Physiol Biochem 11(1-6):175

Saglam D, Atli G, Canli M (2013) Investigations on the osmoregulation of freshwater fish (Oreochromis niloticus) following exposures to metals $(\mathrm{Cd}, \mathrm{Cu})$ in differing hardness. Ecotox Environ Safe 92:79-86. https://doi.org/10.1016/j. ecoenv.2013.02.020

Sakamoto T, McCormick SD (2006) Prolactin and growth hormone in fish osmoregulation. Gen Comp Endocr 147(1):24 30. https://doi.org/10.1016/j.ygcen.2005.10.008

Sbaihi M, Fouchereau-Peron M, Meunier F, Elie P, Mayer I, Burzawa-Gerard E, Vidal B, Dufour S (2010) Reproductive biology of the conger eel from the south coast of Brittany, France and comparison with the Europe eel. J Fish Biol 59: 302-318

Schettino T, Lionetto MG (2003) Cl- absorption in European eel intestine and its regulation. Comp Biochem Phys A 300:63

Seo MY, Mekuchi M, Teranishi K, Kaneko T (2013) Expression of ion transporters in gill mitochondrion-rich cells in Japanese eel acclimated to a wide range of environmental salinity. Comp Biochem Phys A 166:323-332

Shokralla S, Spall JL, Gibson JF, Hajibabaei M (2012) Nextgeneration sequencing technologies for environmental DNA research. Mol Ecol 21(8):1794-1805. https://doi. org/10.1111/j.1365-294X.2012.05538.x

Sudo R, Suetake H, Suzuki Y, Aoyama J, Tsukamoto K (2013a) Profiles of mRNA expression for prolactin, growth hormone, and somatolactin in Japanese eels, Anguilla japonica: the effect of salinity, silvering and seasonal change. Comp Biochem Phys A 164:10

Sudo R, Suetake H, Suzuki Y, Aoyama J, Tsukamoto K (2013b) Profiles of mRNA expression for prolactin, growth hormone, and somatolactin in Japanese eels, Anguilla japonica: the effect of salinity, silvering and seasonal change. Comp Biochem Phys A 164:10-16 
Takei Y (2008) Exploring novel hormones essential for seawater adaptation in teleost fish. Gen Comp Endocr 157(1):3-13. https://doi.org/10.1016/j.ygcen.2008.03.021

Takei Y, Hirano T, Kobayashi H (1979) Angiotensin and water intake in the Japanese eel, Anguilla japonica. Gen Comp Endocr 38(4): 466-475. https://doi.org/10.1016/0016-6480(79)90155-2

Takei Y, Yuge S (2007) The intestinal guanylin system and seawater adaptation in eels. Gen Comp Endocr 152(2-3):339351. https://doi.org/10.1016/j.ygcen.2007.05.005

Tanaka H (2003) Techniques for larval rearing. Eel Biology:427434. https://doi.org/10.1007/978-4-431-65907-5_29

Tanaka H (2014) Progression in artificial seedling production of Japanese eel Anguilla japonica. Fisheries SCI 81:11-19

Tanaka H (2015) Progression in artificial seedling production of Japanese eel Anguilla japonica. Fisheries SCI 81(1):11-19. https://doi.org/10.1007/s12562-014-0821-z

Teles M, Tridico R, Callol A, Fierro-Castro C, Tort L (2013) Differential expression of the corticosteroid receptors GR1, GR2 and MR in rainbow trout organs with slow release cortisol implants. Comp Biochem Phys A 164:506-511

Teranishi K (2010) Spatial, cellular, and intracellular localization of $\mathrm{Na}^{+} / \mathrm{K}^{+}$-ATPase in the sterically disposed renal tubules of Japanese eel. J Histochem Cytochem 58(8):707-719. https://doi.org/10.1369/jhc.2010.955492

Teranishi K, Mekuchi M, Kaneko T (2013) Expression of sodium/ hydrogen exchanger 3 and cation-chloride cotransporters in the kidney of Japanese eel acclimated to a wide range of salinities. Comp Biochem Phys A 164:333-343

Tokarz J, Norton W, Moller G, Hrabe de Angelis M, Adamski J (2013) Zebrafish 20beta-hydroxysteroid dehydrogenase type 2 is important for glucocorticoid catabolism in stress response. PLoS One 8(1):e54851. https://doi.org/10.1371/journal.pone.0054851

Tomanek L (2011) Environmental proteomics: changes in the proteome of marine organisms in response to environmental stress, pollutants, infection, symbiosis, and development. Annu Rev Mar Sci 3(1):373-399. https://doi.org/10.1146 /annurev-marine-120709-142729

Tse WKF, Au DWT, Wong CKC (2006) Characterization of ion channel and transporter mRNA expressions in isolated gill chloride and pavement cells of seawater acclimating eels. Biochem Bioph Res Co 346(4):1181-1190. https://doi. org/10.1016/j.bbrc.2006.06.028

Tse WK, Sun J, Zhang H, Lai KP, Gu J, Sheung Law AY, Yee Yeung BH, Ching Chow S, Qiu JW, Wong CK (2015) Data for transcriptomic and iTRAQ proteomic analysis of Anguilla japonica gills in response to osmotic stress. Data in brief 3: 120-125. https://doi.org/10.1016/j.dib.2015.02.012

Tse WK, Sun J, Zhang H, Law AY, Yeung BH, Chow SC, Qiu JW, Wong CK (2013) Transcriptomic and iTRAQ proteomic approaches reveal novel short-term hyperosmotic stress responsive proteins in the gill of the Japanese eel (Anguilla japonica). J Proteome 89:81-94. https://doi.org/10.1016/j.jprot.2013.05.026

Tsuchida T, Takei Y (1998) Effects of homologous atrial natriuretic peptide on drinking and plasma ANG II level in eels. Am J Physiol-Cell Ph 275:R1605

Tsukada T, Nobata S, Hyodo S, Takei Y (2007) Area postrema, a brain circumventricular organ, is the site of antidipsogenic action of circulating atrial natriuretic peptide in eels. J Exp Biol 210(22):3970-3978. https://doi.org/10.1242/jeb.010645

Tsukada T, Takei Y (2006) Integrative approach to osmoregulatory action of atrial natriuretic peptide in seawater eels. Gen Comp
Endocr 147(1):31-38. https://doi.org/10.1016/j. ygcen.2005.09.009

Unuma T, Kondo S, Tanaka H, Kagawa H, Nomura K, Ohta H (2004) Determination of the rates of fertilization, hatching and larval survival in the Japanese eel, Anguilla japonica, using tissue culture microplates. Aquaculture 241(1-4):345356. https://doi.org/10.1016/j.aquaculture.2004.08.005

Unuma T, Sawaguchi S, Hasegawa N, Tsuda N, Tanaka T, Nomura K, Tanaka H (2012) Optimum temperature of rearing water during artificial induction of ovulation in Japanese eel. Aquaculture 358-359:216-223

Utida S, Kamiya M, and Shirai N (1971) Relationship between the activity of $\mathrm{Na}^{+} / \mathrm{K}^{+}$-activated adenosine triphosphatase and the number of chloride cells in eel gills with special reference to seawater adaption. Comp Biochem Phys A 38, 443,IN449, $447-446$, IN 449,447

Varsamos S, Nebel C, Charmantier G (2005) Ontogeny of osmoregulation in postembryonic fish: a review. Comp Biochem Phys A 141:401-429

Vera JC, Wheat CW, Fescemyer HW, Frilander MJ, Crawford DL, Hanski I, Marden JH (2008) Rapid transcriptome characterization for a nonmodel organism using 454 pyrosequencing. Mol Ecol 17(7):1636-1647. https://doi.org/10.1111/j.1365294X.2008.03666.x

Wang M, You J (2012) Mass spectrometry for protein quantification in biomarker discovery. Methods Mol Biol 815:199225. https://doi.org/10.1007/978-1-61779-424-7_16

Wang X, Yin D, Li P, Yin S, Wang L, Jia Y, Shu X (2015) MicroRNA-sequence profiling reveals novel osmoregulatory microRNA expression patterns in catadromous eel Anguilla marmorata. PLoS One 10(8):e0136383. https://doi. org/10.1371/journal.pone.0136383

Watanabe S, Itoh K, Kaneko T (2016) Prolactin and cortisol mediate the maintenance of hyperosmoregulatory ionocytes in gills of Mozambique tilapia: exploring with an improved gill incubation system. Gen Comp Endocr 232:151-159. https://doi.org/10.1016/j.ygcen.2016.04.024

Westin L (1990) Orientation mechanisms in migrating European silver eel ( Anguilla anguilla): temperature and olfaction. Mar Biol 106(2):175-179. https://doi.org/10.1007 /BF01314798

Wilson JM, Leitão A, Gonçalves AF, Ferreira C, Reis-Santos P, Fonseca A-V, da Silva JM, Antunes JC, Pereira-Wilson C, Coimbra J (2007) Modulation of branchial ion transport protein expression by salinity in glass eels (Anguilla anguilla L.) Mar Biol 151(5):1633-1645. https://doi.org/10.1007 /s00227-006-0579-7

Yuge S, Inoue K, Hyodo S, Takei Y (2003) A novel guanylin family (guanylin, uroguanylin, and renoguanylin) in eels: possible osmoregulatory hormones in intestine and kidney. J Biol Chem 278(25):22726-22733. https://doi.org/10.1074 jjbc.M303111200

Yuge S, Takei Y (2007) Regulation of ion transport in eel intestine by the homologous guanylin family of peptides. Zoologica 24:1222

Zenimoto K, Kitagawa T, Miyazaki S, Sasai Y, Sasaki H, Kimura S (2009) The effects of seasonal and interannual variability of oceanic structure in the western Pacific north equatorial current on larval transport of the Japanese eel Anguilla japonica. J Fish Biol 74(9):1878-1890. https://doi.org/10.1111 /j.1095-8649.2009.02295.x 